\title{
Kidney graft function and arterial stiffness in renal transplant recipients
}

\author{
Zbigniew Heleniak ${ }^{1} \otimes$, Sarah Illersperger², Alicja Dębska-Ślizieńn ${ }^{1}, K^{2}$ lemens Budde ${ }^{2}$ and \\ Fabian Halleck² \\ 'Department of Nephrology, Transplantology and Internal Medicine, Medical University of Gdansk, Gdańsk, Poland; ${ }^{2}$ Medizinische Klinik mit \\ Schwerpunkt Nephrologie und Internistische Intensivmedizin Charité - Universitätsmedizin Berlin, Berlin, Germany
}

Introduction. In renal transplant recipients (RTRs), cardiovascular (CV) complications are associated with nontraditional risk factors, such as a decline in graft function, immunosuppressive therapy, time of dialysis before transplantation, inflammation and anemia. Higher value of arterial stiffness is the consequence of risk factors and it can lead to CV events. The aim of this study was the assessment of the arterial stiffness in RTRs with different value of estimated glomerular filtration rate (eGFR) and its correlation with classical and non-classical CV risk factors. Methods. 344 stable RTRs were enrolled in this study. The arterial stiffness was measured in all participants. The study population was divided in two groups based on the value of eGFR: $201\left(\geq 45 \mathrm{ml} / \mathrm{min} / 1,73 \mathrm{~m}^{2}\right)$ and $143\left(<45 \mathrm{ml} / \mathrm{min} / 1,73 \mathrm{~m}^{2}\right)$. Demographic, immunosuppression status, clinical and biochemical information were referred to a single assessment obtained from medical records in the patients' medical files. Vascular stiffness was determined by an automated oscillometric device. Results. In the group with eGFR $<45 \mathrm{ml} / \mathrm{min} / 1.73$ $\mathrm{m}^{2}$ there were more patients with cardiovascular diseases (CVD) and the participants were older, in comparison to those with eGFR $\geq 45 \mathrm{ml} / \mathrm{min} / 1.73 \mathrm{~m}^{2}$. Arterial stiffness was significantly higher in the group with worse graft function. The analysis showed a significant correlation between age, cardiovascular disease and all arterial stiffness parameters. In addition, a significant correlation was found between all PWV variables and pulse pressure (PP) and pulsatile stress (PS), in the total population and in groups with eGFR $<45 \mathrm{ml} / \mathrm{min} / 1.73 \mathrm{~m}^{2}$ and eGFR $\geq 45$ $\mathrm{ml} / \mathrm{min} / 1.73 \mathrm{~m}^{2}$. The multivariate analysis showed a significant correlation between age, CVD and baPWV left, baPWV right and of PWV in the total population. Arterial stiffness did not differ depending on eGFR. Conclusions. Significant influence of age and CVD on arterial stiffness in RTRs was confirmed and PWV did not differ depending on eGFR. Our findings suggest that PS, as a marker for arterial stiffness, represents an easy and cost-effective tool.

Keywords: pulse wave velocity, kidney transplantation, hypertensive agent

Received: 17 January, 2021; revised: 28 February, 2021; accepted: 13 March, 2021; available on-line: 05 May, 2021

Ðe-mail: zbigniew.heleniak@gumed.edu.pl

Abbreviations: baPWV, brachial-ankle pulse wave velocity; CVD, cardiovascular disease; cfPWV, carotid-femoral pulse wave velocity; eGFR, estimated glomerular filtration rate; KTx, kidney transplantation; RRT, renal replacement therapy; RTRs, renal transplants recipients

\section{INTRODUCTION}

Kidney transplantation ( $\mathrm{KTx}$ ) is the optimal form of renal replacement therapy in patients with the endstage renal disease. During the last decades, although the transplantation procedures and immunosuppressive treatment have improved, the patients still do not live as long as the general population.

In renal transplantation, recipients have a generally decreased nephron mass due to the fact that they receive half of the nephron mass of the donor. Additionally, they lose nephrons during kidney procurement and transplantation. Furthermore, additional factors, such as chronic allograft nephropathy, rejection, recurrence of original kidney disease and infections contribute to the decline in graft function (Seron et al., 2001). The most common causes of death among renal transplant recipients (RTRs) are cardiovascular diseases (CVD) (Kim et al., 2015). The cardiovascular complications in RTRs are not only associated with standard risk factors but also with non-traditional factors, such as immunosuppressive therapy, earlier dialysis therapy, proteinuria, inflammation, anaemia and decline in graft function, specific for this population. Higher value of arterial stiffness is the consequence of the risk factors, and it can lead to CVD (Boutouyrie et al., 2015; Holdaas et al., 2015). Indeed, it has been reported in systematic review and meta-analysis that a rise in pulse wave velocity (PWV) by $1 \mathrm{~m} / \mathrm{s}$ increases the total cardiovascular (CV) events, CV mortality, and all-cause mortality risk, adjusted for age, sex, and other risk factors, by $14 \%, 15 \%$, and $15 \%$, respectively (Foley et al., 1998). Although the risk of the CV disease is attenuated after KTx, the impact of graft function on arterial stiffness still remains unknown, mainly due to small sample studies (Ignace et al., 2001; Zoungas et al., 2004). To our knowledge, this is the first study to assess six parameters of arterial stiffness in the KTx population simultaneously, including the pulsatile stress test parameter, which has not been assessed in the RTRs population.

Therefore, we assessed the arterial stiffness in RTRs with different value of estimated glomerular filtration rate (eGFR) and its correlation with various classical CV risk factors (the presence of CVD, age), non-classical CV factors (graft function, time of renal replacement therapy, anemia, albuminuria, proteinuria) and an immunosuppression regimen. 
Table 1. Characteristics of the study population.

\begin{tabular}{|c|c|c|c|c|}
\hline & Total study population & $\geq 45$ & $<45$ & $\begin{array}{l}\mathrm{p} \\
\mathrm{e} G F R \geq 45 \text { vs eGFR } \\
<45\end{array}$ \\
\hline RTRs n (\%) & 344 & $201(58.4)$ & $143(40.7)$ & 0.003 \\
\hline Sex $M n(\%)$ & $215(62.5)$ & $125(62.2)$ & $89(62.2)$ & 0.89 \\
\hline $\begin{array}{l}\text { Age (years) } \\
\text { Mean value +S.D. }\end{array}$ & $52.7 \pm 13.9$ & $49.5 \pm 13.6$ & $57.1 \pm 13.2$ & 0.03 \\
\hline $\begin{array}{l}\text { BMI }(\mathrm{kg} / \mathrm{m} 2) \\
\text { Mean value }+ \text { S.D. }\end{array}$ & $25.62 \pm 4.78$ & $25.43 \pm 4.76$ & $25.84 \pm 4.79$ & 0.87 \\
\hline $\begin{array}{l}\text { Weight }(\mathrm{kg}) \\
\text { Median }(\mathrm{Q} 1 ; \mathrm{Q} 3)\end{array}$ & $\begin{array}{l}75.5 \\
(63.7 ; 86.2)\end{array}$ & $\begin{array}{l}74.7 \\
(63.3 ; 84.6)\end{array}$ & $\begin{array}{l}76.5 \\
(64.5 ; 87.2)\end{array}$ & 0.68 \\
\hline $\begin{array}{l}\text { Diabetes mellitus n (\%) } \\
\text { (any type 1.2. NODAT) }\end{array}$ & $65(18.4)$ & $39(19.4)$ & $30(20.1)$ & 0.52 \\
\hline Cardiovascular disease $n$ (\%) (CAD. POAD) & $77(22.4)$ & $26(10.4)$ & $51(25.4)$ & 0.001 \\
\hline Myocardial infarction n(\%) & $12(3.5)$ & $5(2.5)$ & $7(4.9)$ & 0.23 \\
\hline Heart failure n (\%) & $90(26.2)$ & $45(22.4)$ & $45(31.5)$ & 0.02 \\
\hline Hypertension n (\%) & $298(86.6)$ & $169(84.1)$ & $129(90.2)$ & 0.68 \\
\hline
\end{tabular}

Reasons of ESRD and KTx: $n(\%)$

\begin{tabular}{|c|c|c|c|c|}
\hline - primary glomerulonephritis & $186(54.1)$ & $120(59.7)$ & $66(46.1)$ & 0.01 \\
\hline - diabetic nephropathy & $5(1.5)$ & $3(1.4)$ & $2(1.4)$ & 0.81 \\
\hline - polycystic kidney disease & $56(16.3)$ & $27(13.4)$ & $29(20.3)$ & 0.002 \\
\hline - tubulointerstitial nephritis & $70(20.3)$ & $39(19.5)$ & $31(21.7)$ & 0.73 \\
\hline - hypertensive nephropathy & $18(5.2)$ & $7(3.5)$ & $11(7.7)$ & 0.52 \\
\hline - unknown etiology & $10(2.9)$ & $6(3)$ & $4(2.8)$ & 0,63 \\
\hline $\begin{array}{l}\text { Time of RRT (months) } \\
\text { before transplantation } \\
\text { Median }(\mathrm{Q} 1 ; \mathrm{Q} 3)\end{array}$ & $\begin{array}{l}58.5 \\
(19 ; 97)\end{array}$ & $\begin{array}{l}36 \\
(4 ; 86)\end{array}$ & $\begin{array}{l}58 \\
(18 ; 91)\end{array}$ & 0.01 \\
\hline $\begin{array}{l}\text { Time after Ktx (months) } \\
\text { Median (Q1;Q3) }\end{array}$ & $\begin{array}{l}73 \\
(28 ; 140)\end{array}$ & $\begin{array}{l}52.4 \\
(12 ; 90.5)\end{array}$ & $\begin{array}{l}94.4 \\
(51 ; 172)\end{array}$ & 0.001 \\
\hline $\begin{array}{l}\text { Preemptive KTx } \\
\mathrm{n}(\%)\end{array}$ & $46(13.4)$ & $35(17.4)$ & $11(7.7)$ & 0.002 \\
\hline $\begin{array}{l}\text { eGFR CKD-EPI } \\
(\mathrm{ml} / \mathrm{min} / 1.73 \mathrm{~m} 2) \\
\text { Mean value +S.D. }\end{array}$ & $50.4 \pm 19.8$ & $63.7 \pm 13.2$ & $30.9 \pm 8.9$ & 0.001 \\
\hline $\begin{array}{l}\text { Potassium mmol/l } \\
\text { Mean value +S.D. }\end{array}$ & $4.3 \pm 0.6$ & $4.2 \pm 0.5$ & $4.5 \pm 0.6$ & 0.04 \\
\hline $\begin{array}{l}\text { Hemoglobin g/dl } \\
\text { Mean value +S.D. }\end{array}$ & $12.7 \pm 1.7$ & $13.3 \pm 1.7$ & $11.9 \pm 1.5$ & 0.61 \\
\hline $\begin{array}{l}\text { CRP mg/l } \\
\text { Median }(\mathrm{Q} 1 ; \mathrm{Q} 3)\end{array}$ & $\begin{array}{l}1.6 \\
(0.7 ; 5.5)\end{array}$ & $\begin{array}{l}1.5 \\
(0.7 ; 4.2)\end{array}$ & $\begin{array}{l}2.0 \\
(0.9 ; 6.4)\end{array}$ & 0.02 \\
\hline $\begin{array}{l}\text { Total cholesterol } \\
\text { Mean value +S.D. }\end{array}$ & $195 \pm 43.7$ & $194 \pm 42.2$ & $197 \pm 45.9$ & 0.66 \\
\hline $\begin{array}{l}\text { Albumin } \mathrm{g} / \mathrm{l} \\
\text { Mean value +S.D. }\end{array}$ & $43.46 \pm 3.28$ & $44.19 \pm 3.08$ & $42.43 \pm 3.29$ & 0.56 \\
\hline $\begin{array}{l}\text { Albuminuria mg/day } \\
\text { Median }(\mathrm{Q} 1 ; \mathrm{Q} 3)\end{array}$ & $\begin{array}{l}41.5 \\
(9.3 ; 145)\end{array}$ & $\begin{array}{l}23.5 \\
(8 ; 76)\end{array}$ & $\begin{array}{l}108.5 \\
(18.5 ; 312)\end{array}$ & 0.001 \\
\hline
\end{tabular}




\begin{tabular}{|c|c|c|c|c|}
\hline $\begin{array}{l}\text { Proteinuria mg/day } \\
\text { Median }(\mathrm{Q} 1 ; \mathrm{Q} 3)\end{array}$ & $\begin{array}{l}171 \\
(114 ; 380)\end{array}$ & $\begin{array}{l}154 \\
(106 ; 245)\end{array}$ & $\begin{array}{l}232 \\
(134 ; 588)\end{array}$ & 0.003 \\
\hline Albuminuria mg/g creatinine Median (Q1;Q3) & $\begin{array}{l}49 \\
(15 ; 156)\end{array}$ & $\begin{array}{l}29 \\
(9 ; 74)\end{array}$ & $\begin{array}{l}111 \\
(30 ; 396.5)\end{array}$ & 0.001 \\
\hline Proteinuria mg/g creatinine Median $(\mathrm{Q} 1 ; \mathrm{Q} 3)$ & $\begin{array}{l}138 \\
(84 ; 322)\end{array}$ & $\begin{array}{l}154 \\
(106 ; 245)\end{array}$ & $\begin{array}{l}280 \\
(114 ; 735)\end{array}$ & 0.004 \\
\hline $\begin{array}{l}\text { Tacrolimus level } \mathrm{ng} / \mathrm{ml} \\
\text { Median }(\mathrm{Q} 1 ; \mathrm{Q} 3)\end{array}$ & $\begin{array}{l}5.78 \\
(4.73 ; 7.59)\end{array}$ & $\begin{array}{l}5.84 \\
(4.92 ; 7.12)\end{array}$ & $\begin{array}{l}5.68 \\
(4.59 ; 8.51)\end{array}$ & 0.12 \\
\hline $\begin{array}{l}\text { Cyclosporine level ng/dl } \\
\text { Median (Q1;Q3) }\end{array}$ & $\begin{array}{l}77.2 \\
(65.9 ; 94.6)\end{array}$ & $\begin{array}{l}76 \\
(68 ; 91.5)\end{array}$ & $\begin{array}{l}83.7 \\
(64.6 ; 102.7)\end{array}$ & 0.19 \\
\hline CsA n (\%) & $73(21.2)$ & $34(16.9)$ & $39(27.3)$ & 0.005 \\
\hline $\mathrm{TAC} \mathrm{n}(\%)$ & $213(61.9)$ & $141(70.1)$ & $72(50.3)$ & 0.01 \\
\hline Steroids n(\%) & $176(51.2)$ & $95(47.3)$ & $81(56.6)$ & 0.01 \\
\hline MMF n (\%) & $150(43.6)$ & $90(44.8)$ & $60(41.9)$ & 0.65 \\
\hline MPS n(\%) & $172(50)$ & $99(49.2)$ & $73(51)$ & 0.78 \\
\hline AZA n (\%) & $5(1.5)$ & $3(1.4)$ & $2(1.4)$ & 0.92 \\
\hline mTOR n (\%) & $10(2.9)$ & $8(4)$ & $2(1.4)$ & 0.67 \\
\hline Belatacept n(\%) & $41(11.9)$ & $16(7.9)$ & $25(17.5)$ & 0.21 \\
\hline ACE inhibitor $n(\%)$ & $89(25.9)$ & $47(23.4)$ & $42(29.4)$ & 0.52 \\
\hline ARB $n(\%)$ & $112(32.6)$ & $58(28.8)$ & $54(37.8)$ & 0.005 \\
\hline Calcium channel blockers n(\%) & $158(45.9)$ & $80(39.8)$ & $78(54.5)$ & 0.003 \\
\hline Beta blockers n (\%) & $242(70.3)$ & $128(63.7)$ & $114(79.7)$ & 0.02 \\
\hline Diuretics n (\%) & $120(34.9)$ & $47(23.4)$ & $73(51)$ & 0.003 \\
\hline Statins n (\%) & 143 (41.6) & 77 (38.3) & $66(46.1)$ & 0.002 \\
\hline EPO n (\%) & 67 (19.5) & $17(8.4)$ & $50(35)$ & 0.001 \\
\hline
\end{tabular}

Abbreviations: eGFR - estimated glomerular filtration rate, Q1 - lower quartile, Q3 - upper quartile, CRP - C reactive protein, RTR - renal transplant recipient, BMI - body mass index, CAD - coronary artery disease, CSA - cyclosporine, RRT - renal replacement therapy, TAC - tacrolimus, POAD - peripheral obliterans artery disease, ESRD - end stage renal disease, Ktx - kidney transplantation

\section{METHODS}

This cross-sectional study enrolled 344 stable RTRs, transplanted between 1994 and 2018, who attended the outpatient unit of the Department of Nephrology Charite Universitätsmedizin Berlin, Germany between February and July, 2018. This research was approved by the Ethics Committee of Charité - Universitätsmedizin Berlin (EA 1/252/17).

Patients gave their written informed consent. The study was conducted following the Helsinki Declaration.

The inclusion criteria were as follows: patient's age $\geq$ 18 years, KTx in the medical history, stable function of the graft and the patient's consent to participate in the study.

On the other hand, lack of consent, advanced neoplasm disease and heart failure in stage IV NYHA were the exclusion criteria.

We analyzed the demographic, immunosuppression status and clinical information, including renal transplant, CV and diabetic status. Information on the presence of the $\mathrm{CV}$ diseases and diabetes was obtained from medical files of our patients. Additionally, the regimen of hypertensive treatment was assessed. Data concerning potassium concentration, hemoglobin, proteinuria, and albuminuria levels were referred to a single assessment obtained from medical records in the patients' medical files. The eGFR $\left(\mathrm{ml} / \mathrm{min} / 1.73 \mathrm{~m}^{2}\right)$ was calculated based on the CKD-EPI equation. Furthermore, we investigated the parameters of arterial stiffness: brachial-ankle and carotid-femoral pulse wave velocity (baPWV left and right, cfPWV), ankle-brachial index (ABI) and pulse pressure (PP left and right) in each patient using the ABI system 100 (Boso Bosch and Sohn Germany). This system includes four cuffs (2 leg and 2 arm cuffs each) allowing concomitant blood pressure measurement on all limbs. This prevents ABI measurement inaccuracy due to blood pressure fluctuation. All parameter readings for each leg were obtained in a quiet room, after 5 minutes of rest in the recumbent position. Additionally, pulsatile stress (PS) (left and right) was assessed as a marker of arterial stiffness by using the equation: pulsatile stress test $=$ heart rate $\times$ pulse pressure. Moreover, the value of systolic and diastolic blood pressure (SBP, DBP) was obtained. 
Table 2. Blood pressure and arterial stiffness in the study population

\begin{tabular}{|c|c|c|c|c|}
\hline & Total study population & $\geq 45$ & $<45$ & $\begin{array}{l}\mathrm{p} \\
\mathrm{e} G F R \geq 45 \text { vs eGFR }<45\end{array}$ \\
\hline $\begin{array}{l}\text { SBP right arm }(\mathrm{mmHg}) \\
\text { Mean value+S.D. }\end{array}$ & $140.7 \pm 17.7$ & $137.4 \pm 16.6$ & $145.7 \pm 18.1$ & 0.01 \\
\hline $\begin{array}{l}\text { SBP left arm }(\mathrm{mmHg}) \\
\text { Mean value +S.D. }\end{array}$ & $139.6 \pm 20.1$ & $138.2 \pm 18.7$ & $141.6 \pm 21.9$ & 0.34 \\
\hline $\begin{array}{l}\text { DBP right arm }(\mathrm{mmHg}) \\
\text { Mean value }+ \text { S.D. }\end{array}$ & $85.8 \pm 10.3$ & $85.4 \pm 9.6$ & $86.3 \pm 11.2$ & 0.76 \\
\hline $\begin{array}{l}\text { DBP left arm }(\mathrm{mmHg}) \\
\text { Mean value +S.D. }\end{array}$ & $85.7 \pm 10.9$ & $85.5 \pm 9.9$ & $85.6 \pm 12.2$ & 0.83 \\
\hline $\begin{array}{l}\text { PP right arm }(\mathrm{mmHg}) \\
\text { Mean value }+ \text { S.D. }\end{array}$ & $54.6 \pm 14.7$ & $51.9 \pm 13.3$ & $58.8 \pm 15.8$ & 0.03 \\
\hline $\begin{array}{l}\text { PP left arm }(\mathrm{mmHg}) \\
\text { Mean value }+ \text { S.D. }\end{array}$ & $54.0 \pm 15.9$ & $52.7 \pm 14.8$ & $56.0 \pm 17.5$ & 0.35 \\
\hline $\begin{array}{l}\text { Pulsatile stress right } \\
\text { Mean value +S.D. }\end{array}$ & $3521 \pm 1012$ & $3350 \pm 860$ & $3800 \pm 1178$ & 0.01 \\
\hline $\begin{array}{l}\text { Pulsatile stress left } \\
\text { Mean value +S.D. }\end{array}$ & $3520 \pm 1225$ & $3442 \pm 1111$ & $3644 \pm 1399$ & 0.24 \\
\hline $\begin{array}{l}\text { ABI right } \\
\text { Mean value+S.D. }\end{array}$ & $1.08 \pm 0.17$ & $1.09 \pm 0.18$ & $1.07 \pm 0.16$ & 0.76 \\
\hline $\begin{array}{l}\text { ABI left } \\
\text { Mean value +S.D. }\end{array}$ & $1.09 \pm 0.13$ & $1.09 \pm 0.11$ & $1.09 \pm 0.16$ & 0.86 \\
\hline $\begin{array}{l}\text { ba PWV right }(\mathrm{m} / \mathrm{s}) \\
\text { Median }(\mathrm{Q} 1 ; \mathrm{Q} 3)\end{array}$ & $\begin{array}{l}11.8 \\
(10.7 ; 13.3)\end{array}$ & $\begin{array}{l}11.5 \\
(10.5 ; 12.5)\end{array}$ & $\begin{array}{l}12.7 \\
(11.6 ; 15.2)\end{array}$ & 0.02 \\
\hline $\begin{array}{l}\text { ba PWV left }(\mathrm{m} / \mathrm{s}) \\
\text { Median }(\mathrm{Q} 1 ; \mathrm{Q} 3)\end{array}$ & $\begin{array}{l}12.0 \\
(10.9 ; 13.5)\end{array}$ & $\begin{array}{l}12.0 \\
(10.5 ; 13.0)\end{array}$ & $\begin{array}{l}12.5 \\
(11.3 ; 14.1)\end{array}$ & 0.03 \\
\hline $\begin{array}{l}\text { cf PWV (m/s) } \\
\text { Median (Q1;Q3) }\end{array}$ & $\begin{array}{l}7.9 \\
(6.9 ; 9.5)\end{array}$ & $\begin{array}{l}7.9 \\
(6.7 ; 8.5)\end{array}$ & $\begin{array}{l}8.4 \\
(7.3 ; 10.6)\end{array}$ & 0.02 \\
\hline
\end{tabular}

Abbreviation: ABI - ankle brachial index, baPWV - brachial-ankle, pulse wave velocity, cfPWV - carotid-femoral pulse wave velocity, DBP - diastolic blood pressure, SBP - systolic blood pressure, Q1 - lower quartile, Q3-upper quartile

\section{Statistical Analyses}

Statistical analyses were performed using the STATSTICA 13.3 PL for Windows software package. Categorical variables are presented as absolute numbers (percentages). Continuous variables are presented as mean value \pm standard deviation (S.D.) or as median and interquartile range (IQR) for highly skewed variables. Differences in the distribution of continuous variables were assessed using the two-sample t-test or the Mann-Whitney U-test, respectively. The $\mathrm{chi}^{2}$ test was used for the categorical variables. Correlation coefficients were calculated using the Spearman test. Additionally, a simple linear regression model was used to model the relationship between a scalar response (or dependent variable) and one or more explanatory variables (or independent variables). The Shapiro-Wilk test was used to assess normality. In all statistical tests, a $p$-value $<0.05$ was considered as statistically significant. To assess the relation between renal function and arterial stiffness with respect to age as a possible contributing factor, analysis of covariance (ANCOVA) was performed.

\section{RESULTS}

\section{Study population characteristics}

Overall, 344 patients were enrolled in this study. The study population was divided into two groups based on the value of eGFR. 201 and 143 RTRs were qualified to the $\geq 45 \mathrm{ml} / \mathrm{min} / 1.73 \mathrm{~m}^{2}$ (median of creatinine 1.23 $\mathrm{mg} / \mathrm{dl}$, mean eGFR $63.7 \mathrm{ml} / \mathrm{min} / 1.73 \mathrm{~m}^{2}$ ) and $<45 \mathrm{ml} /$ $\mathrm{min} / 1.73 \mathrm{~m}^{2}$ (median of creatinine $2.06 \mathrm{mg} / \mathrm{dl}$, mean eGFR $30.9 \mathrm{ml} / \mathrm{min} / 1.73 \mathrm{~m}^{2}$ ) groups, respectively.

Precise characteristics of these two groups are presented in Table 1 . The patients in the $<45 \mathrm{ml} /$ $\mathrm{min} / 1.73 \mathrm{~m}^{2}$ group were older (49.5 vs 57.1 years, $p=0.03)$ as compared to the $\geq 45 \mathrm{ml} / \mathrm{min} / 1.73 \mathrm{~m}^{2}$ participants. There were significantly more males in both groups of patients. The main causes of end-stage renal disease (ESRD) in the study population were glomerulonephritis and tubulointerstitial nephropathy. The level of albumin in the blood and hemoglobin was similar in both groups. On the other hand, proteinuria and albuminuria were significantly lower in the eGFR $\geq 45 \mathrm{ml} / \mathrm{min} / 1.73 \mathrm{~m}^{2}$ patients when compared to the $\mathrm{eGFR}<45 \mathrm{ml} / \mathrm{min} / 1.73 \mathrm{~m}^{2}$ group. Additionally, the C-reactive protein (CRP) was higher in the group with lower eGFR. In the group with eGFR $\geq 45$ $\mathrm{ml} / \mathrm{min} / 1.73 \mathrm{~m}^{2}$ there were less patients with CVD, such as coronary artery disease (CAD) and/or peripheral obliterans artery disease (POAD) when compared to the eGFR $<45 \mathrm{ml} / \mathrm{min} / 1.73 \mathrm{~m}^{2}$ group $(10.4 \%$ vs $25.4 \%, p=0.001)$ and heart failure (HF) $(22.4 \%$ vs $31.5 \%, p=0.02)$.

There were differences in terms of the time of RRT before transplantation (36 vs 58 months, $p=0.01$ ), and time after transplantation between both groups (52.5 vs 94.4 months, $p=0.001)$ in the eGFR $\geq 45 \mathrm{ml} /$ $\mathrm{min} / 1.73 \mathrm{~m}^{2}$ and $\mathrm{eGFR}<45 \mathrm{ml} / \mathrm{min} / 1.73 \mathrm{~m}^{2}$ groups, respectively. 
Table 3. Spearman's rank correlation coefficient between age, cardiovascular disease and arterial stiffness parameters in the total population and groups with different values of estimated glomerular filtration rate.

\begin{tabular}{|c|c|c|c|c|c|c|}
\hline & \multicolumn{2}{|c|}{ Total population } & \multicolumn{2}{|c|}{$\mathrm{eGFR} \geq 45$} & \multicolumn{2}{|c|}{ eGFR $<45$} \\
\hline & age & CVD & age & CVD & age & CVD \\
\hline parameter & $r$ & & $r$ & & $r$ & \\
\hline PP right & 0.43 & 0.26 & 0.34 & 0.19 & 0.44 & 0.26 \\
\hline PP left & 0.32 & 0.27 & 0.34 & 0.30 & 0.37 & 0.16 \\
\hline PS right & 0.41 & 0.25 & 0.31 & 0.17 & 0.45 & 0.26 \\
\hline PS left & 0.40 & 0.21 & 0.39 & 0.24 & 0.28 & 0.25 \\
\hline $\mathrm{ABI}$ right & -0.24 & -0.25 & -0.16 & -0.24 & -0.33 & -0.26 \\
\hline ABI left & -0.17 & -0.20 & -0.09 & -0.19 & -0.29 & -0.22 \\
\hline baPWV right & 0.60 & 0.41 & 0.54 & 0.27 & 0.61 & 0.47 \\
\hline baPWV left & 0.57 & 0.32 & 0.54 & 0.31 & 0.57 & 0.30 \\
\hline cf PWV & 0.59 & 0.39 & 0.54 & 0.26 & 0.58 & 0.45 \\
\hline
\end{tabular}

For all results in the table the $p$ value was $<0.05$. Abbreviations: $r$ - correlation coefficient, CVD - cardiovascular disease, eGFR - estimated glomerular filtration rate, baPWV - brachial-ankle pulse wave velocity, cfPWV - carotid-femoral pulse wave, PP - pulse pressure, PS - pulsatile stress test, $A B I$ - ankle-brachial index

\section{Immunosuppressive regimen in the study population}

Calcineurin inhibitors were used in $83.1 \%$. Cyclosporine (CsA) was administered in $16.9 \%$ vs $27.3 \%$ $(p=0.005)$, tacrolimus (TAC) $70.1 \%$ vs $50.3 \% \quad(p=0.01)$ and steroids $47.3 \%$ vs $56.6 \%(p=0.01)$ in $\geq 45 \mathrm{ml} /$ $\min / 1.73 \mathrm{~m}^{2}$ and $<45 \mathrm{ml} / \mathrm{min} / 1.73 \mathrm{~m}^{2}$ groups, respectively. Additionally, the levels of these drugs were not different between groups.

There was no difference observed in terms of MMF, MPS, azathioprine, mTOR and belatacept agents between both groups.

\section{Hypertensive regimen and erythropoietin treatment in the study population}

Calcium channel blockers, diuretics and beta blockers were administered in $39.8 \%$ vs $54.5 \% \quad(p=0.003)$, $23.4 \%$ vs $51 \% \quad(p=0.003)$ and $63.7 \%$ vs $79.7 \% \quad(p=0.02)$ in the eGFR $\geq 45 \mathrm{ml} / \mathrm{min} / 1.73 \mathrm{~m}^{2}$ and eGFR $<45 \mathrm{ml} /$ $\mathrm{min} / 1.73 \mathrm{~m}^{2}$ groups, respectively. Overall, $59.3 \%$ of screened RTRs received a renin angiotensin aldosterone system (RAAS) blockade. Angiotensin convertase inhibitors (ACEIs) and angiotensin receptor blockers (ARBs), were used in $23.4 \%$ vs $29.4 \% \quad(p=0.52)$ and $28.8 \%$ vs $37.8 \%(p=0.005)$ in the $\geq 45 \mathrm{ml} / \mathrm{min} / 1.73 \mathrm{~m}^{2}$ and $<45 \mathrm{ml} / \mathrm{min} / 1.73 \mathrm{~m}^{2}$ groups, respectively.

\section{Blood pressure control and arterial stiffness in the study population}

The control of blood pressure (BP) was almost similar in both groups of patients. Arterial stiffness parameters, such as ABI, pulse pressure and pulsatile stress test were indistinguishable, nearly in both cohorts. All PWV values were significantly higher in the group with eGFR $<45$ $\mathrm{ml} / \mathrm{min} / 1.73 \mathrm{~m}^{2}$ when compared to $e G F R \geq 45 \mathrm{ml} /$ $\min / 1.73 \mathrm{~m}^{2}$ (Table 2).

\section{Univariate analysis}

The univariate analysis showed significant correlation between age, cardiovascular disease and all arterial stiffness parameters in the total population, and in groups with eGFR $<45 \mathrm{ml} / \mathrm{min} / 1.73 \mathrm{~m}^{2}$ and $e G F R \geq 45 \mathrm{ml} /$ $\mathrm{min} / 1.73 \mathrm{~m}^{2}$ (Table 3). Moreover, the analysis did not reveal a significant correlation between arterial stiffness parameters and immunosuppressive drug administration, the level of tacrolimus and cyclosporine, CRP, albuminuria, proteinuria, hemoglobin level and time of RRT.

In addition, a significant correlation was found between all PWV variables and the other arterial stiffness parameters, such as PP and PS in the total population and groups with eGFR $<45 \mathrm{ml} / \mathrm{min} / 1.73 \mathrm{~m}^{2}$ and $\mathrm{eGFR} \geq 45 \mathrm{ml} / \mathrm{min} / 1.73 \mathrm{~m}^{2}$ (Table 4 ).

Table 4. Spearman's rank correlation coefficient pulse wave velocity and the other arterial stiffness parameters in the total population and groups with different values of estimated glomerular filtration rate.

\begin{tabular}{|c|c|c|c|c|c|c|c|c|c|}
\hline \multirow[b]{2}{*}{ parameter } & \multicolumn{3}{|c|}{ Total population } & \multicolumn{3}{|l|}{$e G F R \geq 45$} & \multicolumn{3}{|l|}{ eGFR<45 } \\
\hline & baPWV right & baPWV left & cf PWV & baPWV right & baPWV left & cf PWV & baPWV right & baPWV left & cf PWV \\
\hline & $r$ & & & $r$ & & & $r$ & & \\
\hline PP right & 0.35 & 0.35 & 0.37 & 0.28 & 0.34 & 0.33 & 0.37 & 0.30 & 0.35 \\
\hline PP left & 0.39 & 0.42 & 0.40 & 0.37 & 0.43 & 0.42 & 0.39 & 0.38 & 0.35 \\
\hline PS right & 0.46 & 0.39 & 0.44 & 0.40 & 0.37 & 0.37 & 0.51 & 0.39 & 0.41 \\
\hline PS left & 0.42 & 0.42 & 0.40 & 0.41 & 0.44 & 0.42 & 0.43 & 0.40 & 0,37 \\
\hline
\end{tabular}

For all results in the table the $p$ value was $<0.05$. Abbreviations: $r$ - correlation coefficient, eGFR - estimated glomerular filtration rate, baPWV brachial-ankle pulse wave velocity, cfPWV - carotid-femoral pulse wave, PP - pulse pressure, PS - pulsatile stress test 
Table 5. Linear regression (multivariate analysis) in the total population

\begin{tabular}{|c|c|c|c|c|}
\hline A & baPWV right & & & \\
\hline parameter & B & Standard error & Beta & $p$ \\
\hline Age & 0.08 & 0.009 & 0.429 & $<0.001$ \\
\hline CVD & 0.67 & 0.160 & 0.218 & $<0.001$ \\
\hline eGFR & -0.02 & 0.006 & -0.146 & 0.003 \\
\hline Adjusted R2 & 0.374 & & & \\
\hline B & baPWV left & & & \\
\hline parameter & B & Standard error & Beta & $p$ \\
\hline Age & 0.09 & 0.011 & 0.487 & $<0.001$ \\
\hline CVD & 0.46 & 0.202 & 0.131 & 0.02 \\
\hline eGFR & -0.0009 & 0.007 & -0.007 & 0.89 \\
\hline Adjusted $\mathrm{R}^{2}$ & 0.295 & & & \\
\hline C & cfPWV & & & \\
\hline parameter & B & Standard error & Beta & $p$ \\
\hline Age & 0.07 & 0.009 & 0.430 & $<0.001$ \\
\hline CVD & 0.68 & 0.158 & 0.223 & $<0.001$ \\
\hline eGFR & -0.007 & 0.005 & -0.059 & 0.23 \\
\hline Adjusted $\mathrm{R}^{2}$ & 0.331 & & & \\
\hline
\end{tabular}

Abbreviations: B - regression coefficient, eGFR - estimated glomerular filtration rate, CVD - cardiovascular disease, baPWV - brachial-ankle pulse wave velocity, cfPWV - carotid-femoral pulse wave

\section{Multivariate analysis}

The multivariate analysis with a model including age, CVD and eGFR was performed for the total study population only. The results showed a significant correlation between age, CVD and baPWV left, baPWV right and cf PWV in the total population (Table $5 \mathrm{a}-\mathrm{c}$ ). A significant relationship was only between eGFR and baPWV right. There was no association of eGFR with baPWV left and cfPWV values in the study population.

In the analysis of covariance (ANCOVA), arterial stiffness did not differ depending on eGFR in the total population adjusted for mean age (51.85) (Table 6 a-c).

\section{DISCUSSION}

In the study presented here, it was shown that CVD and age corresponded independently with the arterial stiffness parameters regardless of the eGFR value. Moreover, a multivariate analysis and ANCOVA test did not reveal a significant influence of eGFR on PWV. Finally, PWV correlated with PP and PS in the study population.

PWV is a noninvasive and reproducible method currently considered as the gold standard for aortic stiffness measurement, and a marker of target organ damage in the European Society of Hypertension-European Society of Cardiology guidelines (Van Bortel et al., 2012, Mancia et al., 2007). Indeed, arterial stiffness was reported as an independent predictive factor for coronary heart disease, fatal stroke, total and CV mortality in essential hypertensive, diabetic, and endstage renal disease (ESRD) populations (Boutouyrie et al., 2002; Cruickshank et al., 2002; Briet et al., 2006). However, little is known about arterial stiffness in RTRs. Renal transplantation may exert beneficial effects on aortic stiffness evolution through kidney function recovery. Thus, it is difficult to extrapolate the results of studies carried out on ESRD patients to RTRs.

Cf-PWV had independent predictive value for allcause and CV mortality, also in patients with hypertension, type 2 diabetes, ESRD and in RTRs (Verbeke et al., 2011; Cruickshank et al., 2002; Blacher et al., 1999).

Renal transplantation improves survival and decreases $\mathrm{CV}$ events when compared to hemodialysis, but the CV risk is still high when compared to the general population (Meier-Kriesche et al., 2004). The improvement of aortic stiffness in RTRs is not obvious. Donor and recipient age, the improvement of blood pressure and donor characteristics - living/cadaveric - are major determinants of aortic stiffness progression after transplantation. Delahousse and others measured cfPWV and showed an association between cfPWV and the recipient's age (Delahousse et al., 2008). Another study performed by Li and others showed that in RTRs, the age and RRT were positively correlated with an increase in PWV (Li et al., 2018). On the contrary, Saran et al. did not confirm the relationship between the time of dialysis before transplantation and PWV in RTRs (Saran et al., 2018). Finally, Melilli and others revealed that the age was associated with a significant increase in cf-PWV, regardless of the immunosuppressive protocol and graft function (Melilli at al., 2015).

Not unexpectedly, older age and CV history were identified as independent determinants of pulse wave velocity. The observation of direct association between CV history and arterial stiffness is in agreement with previous studies in both, hemodialysis and RTR (Rosas at al., 2005; Raggi et al., 2002).

The results of our study were similar and showed that the recipient's age and CVD were essential risk factors for higher pulse wave velocity in RTRs. 
Table 6. The analysis of covariance (ANCOVA) in the total population

\begin{tabular}{|c|c|c|c|c|c|}
\hline A & baPWV right & & & & \\
\hline parameter & Type III sum of squares & Mean square & $\mathrm{F}$ & $p$ & Partial Eta squared \\
\hline Intercept & 908,70 & 908,70 & 235.61 & 0.000 & 0.4534 \\
\hline Age & 285.41 & 285.41 & 74.00 & 0.000 & 0.2067 \\
\hline CVD & 89.46 & 89.46 & 23.20 & 0.000 & 0.0751 \\
\hline eGFR bin & 0.466 & 0.466 & 0.12 & 0.728 & 0.004 \\
\hline Error & 1095.33 & 3.86 & & & \\
\hline B & baPWV left & & & & \\
\hline parameter & Type III sum of squares & Mean square & $\mathrm{F}$ & $p$ & Partial Eta squared \\
\hline Intercept & 708.23 & 708.23 & 153.26 & 0.000 & 0.3829 \\
\hline Age & 313.38 & 313.38 & 67.82 & 0.000 & 0.2154 \\
\hline CVD & 23.20 & 23.20 & 5.02 & 0.020 & 0.019 \\
\hline eGFR bin & 5.78 & 5.78 & 1.25 & 0.261 & 0.005 \\
\hline Error & 1141.40 & 4.62 & & & \\
\hline $\mathrm{C}$ & cfPWV & & & & \\
\hline parameter & Type III sum of squares & Mean square & $\mathrm{F}$ & $p$ & Partial Eta squared \\
\hline Intercept & 324.94 & 324.94 & 87.17 & 0.000 & 0.223 \\
\hline Age & 257.57 & 257.57 & 69.09 & 0.000 & 0.185 \\
\hline CVD & 75.49 & 75.49 & 20.25 & 0.000 & 0.062 \\
\hline eGFR bin & 1.34 & 1.34 & 0.36 & 0.549 & 0.001 \\
\hline Error & 1129.48 & 3.73 & & & \\
\hline
\end{tabular}

Abbreviations: eGFR- estimated glomerular filtration rate, CVD- cardiovascular disease, baPWV - brachial-ankle pulse wave velocity, cfPWV - carotid-femoral pulse wave

Zanoli and others (Zanoli et al., 2019) showed that the large arterial stiffening starts early during CKD, even in participants with a very mild reduction in the renal function. Verbeke and others (Verbeke et al., 2007) revealed the presence of higher arterial stiffness in RTRs with an incomplete restoration of eGFR.

Our results were similar to the above-cited articles because arterial stiffness parameters were higher in patients with lower eGFR, but it was mainly due to the older age and higher prevalence of CVD in this group.

From the clinician's point of view, the patient's qualification for kidney transplantation should as fast as possible in order to prevent CV complications related to the period of dialysis therapy.

PS may be more preferable to PWV, as it additionally reflects the sympathetic activity and does not require additional measures as pulsatile stress is determined by pulse pressure and heart rate. There is little data in the literature on the use of this parameter for assessment of arterial stiffness in RTRs. Baumann et al demonstrated that pulsatile stress was associated with albuminuria in RTRs. By contrast, elevated PWV was not associated with the microcirculatory damage (Baumann et al., 2010). PS distorts the arterial wall, thereby promoting arteriosclerosis. Moreover, transplanted kidneys receive a relatively high intrarenal flow at rest during both, the systole and diastole (Safar et al., 2007).

On the other hand, the autonomic nervous system is often enhanced, in particular in the muscular arteries of RTRs (Guizar-Mendoza et al., 2006; Krespi et al., 1998). Our study did not show a relationship of PS with albuminuria, proteinuria and eGFR, but age, CVD and PWV corresponded with this parameter.

\section{LIMITATIONS}

There are several limitations of this study that should be considered when interpreting our conclusions. First, the study population was a heterogeneous group, with different comorbidities, and dissimilar times of dialysis and the period after renal transplantation. Moreover, there were no data concerning the type and age of donors. Secondly, the use of office blood pressure readings, done once, to monitor the quality of blood pressure control may be subject to a significant error due to the white-coat syndrome. In reality, therefore, treatment results may be even better. In addition, the assessment of antihypertensive treatment was based on medical records. Therefore, there would be small differences between this data and real life. Thirdly, there were no data concerning the level of glycated hemoglobin, the aspirin or clopidogrel administration, the time of CVD and diabetes diagnosis. However, despite these limitations, this study highlights some important information for the RTRs community.

\section{CONCLUSIONS}

A significant influence of age and CVD on arterial stiffness in RTRs was confirmed.

PWV did not differ depending on eGFR. Our findings suggest that PS, as a marker for arterial stiffness, represents an easy and cost-effective tool as determination of pulsatile stress is based on blood pressure and heart rate, and does not require extra measures. These data are valuable from a clinical point of view in everyday clinical 
practice. A prospective and randomized study with follow up is necessary to confirm our results.

\section{Acknowledgements}

Not Applicable

\section{Ethical approval and consent to participate}

This study was approved by The Ethics Committee of Charité - Universitätsmedizin Berlin (EA 1/252/17).

On behalf of all authors, the corresponding author states that there is no conflict of interest. All procedures performed in studies involving human participants were under the ethical standards of the institutional and/or national research committee and with the 1964 Helsinki declaration and its later amendments or comparable ethical standards. Informed consent was obtained from all individual participants included in the study.

\section{Consent for publication}

Not Applicable

\section{Competing interests}

The authors declare that they have no competing interests.

\section{Authors' contributions}

Substantial contributions to the conception or design of the work; or the acquisition, analysis, or interpretation of data for the work: ZH, SI, ADS, KB, FH.

Drafting the work or revising it critically for important intellectual content: ZH, ADŚ, KB $\mathrm{KB}$

Final approval of the version to be published: ADŚ,

Agreement to be accountable for all aspects of the work in ensuring that questions related to the accuracy or integrity of any part of the work are appropriately investigated and resolved: ZH, ADŚ, KB, FH. All authors have read and approved the manuscript.

\section{Funding}

No funding source

\section{Availability of data and materials}

The datasets used for this study are available from the corresponding author on reasonable request.

\section{REFERENCES}

Baumann M, Rui Pan Ch, Roos M, von Eynatten M, Sollinger D, Lutz J, Heemann U (2010) Pulsatile stress correlates with (micro-)albuminuria in renal transplant recipients. Tranpl. Int. 23: 292-298. https:// doi.org/10.1111/j.1432-2277.2009.00981.x

Blacher J, Guerin AP, Pannier B, Marchais SJ, Safar ME, London GM (1999) Impact of aortic stiffness on survival in end-stage renal disease. Circulation 99: 2434-2439. https://doi.org/10.1161/01. cir.99.18.2434

Boutouyrie P, Fliser D, Goldsmith D, Covic A, Wiecek A, Ortiz A, Martinez-Castelao A, Lindholm B, Massy ZA, Suleymanlar G, Sicari R, Gargani L, Parati G, Mallamaci F, Zoccali C, London GM (2015) Assessment of artery stiffness for clinical and epidemiological studies: renal and cardiovascular medicine registry. Nephrol. Dial. Transplant. 29: 232-239. https://doi.org/10.1093/ndt/gft309

Boutouyrie P, Tropeano AI, Asmar R, Gautier I, Benetos A, Lacolley P, Laurent S (2002) Aortic stiffness is an independent predictor of primary coronary events in hypertensive patients: a longitudinal study. Hypertension 39: 10-15. https://doi.org/10.1161/ hy0102.099031

Briet M, Bozec E, Laurent S, Fassot C, London GM, Jacquot C, Froissart M, Houillier P, Boutouyrie P (2006) Arterial stiffness and en- largement in mild-to-moderate chronic kidney disease. Kidney. Int. 69: 350-357. https://doi.org/10.1038/sj.ki.5000047

Cruickshank K, Riste L, Anderson SG, Wright JS, Dunn G, Gosling RG (2002) Aortic pulse-wave velocity and its relationship to mortality in diabetes and glucose intolerance:an integrated index of vascular function? Circulation. 106: 2085-2090. https://doi. org/10.1161/01.cir.0000033824.02722.f7

Delahousse M, Chaignon M, Mesnard L, Boutouyrie P, Safar ME, Thierry Lebret T, Pastural-Thaunat M, Tricot L, Kolko-Labadens A, Karras A, Haymann JP (2008) Aortic stiffness of kidney transplant recipients correlates with donor age. J. Am. Soc. Nephrol. 19: 798-805. https://doi.org/10.1681/ASN.2007060634

Foley RN, Parfrey PS, Sarnak MJ (1998) Clinical epidemiology of cardiovascular disease in chronic renal disease. Am. J. Kidney. Dis. 32: S112-S119. https://doi.org/10.1053/ajkd.1998.v32.pm9820470

Guízar-Mendoza JM, Amador-Licona N, Lozada EE, Rodriguez L, Gutiérrez-Navarro M, Dubey-Ortega LA, Trejo-Bellido J, de Jesús Encarnación J, Cruz Ruiz-Jaramillo MD (2006) Left ventricular mass and heart sympathetic activity after renal transplantation in children and young adults. Pediatr. Nephrol. 21: 1413-1418. https:// doi.org/10.1007/s00467-006-0238

Holdaas H, de Fijter JW, Cruzado JM, Massari P, Nashan B, Kanellis J, Witzke O, Gutierrez-Dalmau A, Turkmen A, Wang Z, Lopez P, Bernhardt P, Kochuparampil J, van der Giet M, Murbraech K (2017) Cardiovascular parameters to 2 years after kidney transplantation following early switch to everolimus without calcineurin inhibitor therapy: an analysis of the randomized ELEVATE study. Transplantation 101: 2612-2620. https://doi.org/10.1097/ TP.0000000000001739

Ignace S, Utescu MS, De Serres SA, Marquis K, Gaudreault-Tremblay MM, Larivière R, Côté I, Houde I, Lebel M, Agharazii M (2011) Age-related and blood pressure-independent reduction in aortic stiffness after kidney transplantation. J. Hypertens. 29: 130-136. https://doi.org/10.1097/HJH.0b013e32833f5e68

Kim HS, Seung J, Lee JH, Chung BH, Yang CW (2015) Clinical significance of pre-transplant arterial stiffness and the impact of kidney transplantation on arterial stiffness. PLOS One. 10: v1-8. https://doi. org/10.1371/journal.pone.0139138

Li Z, Qin Y, Du L, Luo X (2018) An improvement of carotid intimamedia thickness and pulse wave velocity in renal transplant recipients. BMC. Med. Imaging. 18: 23. https://doi.org/10.1186/s12880018-0263-7

Mancia G, De Backer G, Dominiczak A, Cifkova R, Fagard R, Germano G, Grassi G, Heagerty AM, Kjeldsen SE, Laurent S, Narkiewicz K, Ruilope L, Rynkiewicz A, Schmieder RE, Boudier HS, Zanchetti A (2007) Guidelines for the management of arterial hypertension: The Task Force for the Management of Arterial Hypertension of the European Society of Hypertension (ESH) and of the European Society of Cardiology (ESC). Eur. Heart. J. 28: 1462-536. https:// doi.org/10.1093/eurheartj/ehm236

Meier-Kriesche HU, Schold JD, Srinivas TR, Reed A, Kaplan B (2004) Kidney transplantation halts cardiovascular disease progression in patients with end-stage renal disease. Am. J. Transplant. 4: 16621668. https://doi.org/10.1111/j.1600-6143.2004.00573.x

Melilli E, Bestard-Matamoros O, Manonelles-Montero A, Sala-Bassa N, Mast R, Grinyó-Boira JM, Cruzado JM (2015) Arterial stiffness in kidney transplantation: a single center case-control study comparing belatacept versus calcineurin inhibitor immunosuppressive based regimen. Nefrologia. 35: 58-65. https://doi.org/10.3265/Nefrologia. pre2014.Sep.12615

Raggi P, Boulay A, Chasan-Taber S, Amin N, Dillon M, Burke SK, Chertow GM (2002). Cardiac calcification in adult hemodialysis patients: a link between end-stage renal disease and cardiovascular disease? J. Am. Coll. Cardiol. 39: 695-701. https://doi.org/10.1016/ s0735-1097(01)01781-8

Rosas SE, Mensah K, Weinstein RB, Bellamy SL, Rader DJ (2005). Coronary artery calcification in renal transplant recipients. $\mathrm{Am}$. J. Transplant. 5: 1942-1947. https://doi.org/10.1111/j.16006143.2005.00955.x

Safar ME, Lacolley P (2007) Disturbance of macro- and microcirculation: relations with pulse pressure and cardiac organ damage. Am. J. Physiol. Heart. Circ. Physiol. 293: H1-H7. https://doi.org/10.1152/ ajpheart.00063.2007

Saran M, Czyżewski L, Wyzgał J, Pacek A, Szarpak L (2018) Comparative analysis of arterial stiffness and body composition in early and late periods after kidney transplantation. Transplant. Proc. 50: 18291833. https://doi.org/10.1016/j.transproceed.2018.03.110

Seron D, Moresco F, Grinyo JM (2001) Prevention and management of late renal allograft dysfunction. J. Nephrol. 14: 71-79

Van Bortel LM, Laurent S, Boutouyrie P, Chowienczyk P, Cruickshank JK, Backer TD, Filipovsky J, Huybrechts S, Mattace-Raso FUS, Protogerou AD, Schillaci G, Segers P, Vermeersch S, Weber T, Artery Society; European Society of Hypertension Working Group on Vascular Structure and Function; European Network for Noninvasive Investigation of Large Arteries (2012) Expert consensus document on the measurement of aortic stiffness in daily practice us- 
ing carotid-femoral pulse wave velocity. J. Hypertens. 30: 445-448. https://doi.org/10.1097/HJH.0b013e32834fa8b0

Verbeke F, Biesen WV, Peeters P, Bortel LM, Vanholder RC (2007) Arterial stiffness and wave reflections in renal transplant recipients. Nephrol. Dial. Transplant. 22: 3021-3027. https://doi.org/10.1093/ ndt/gfm 379

Verbeke F, Marechal C, Van Laecke S, Van Biesen W, Devuyst O, Van Bortel LM, Jadoul M, Vanholder R (2011) Aortic stiffness and central wave reflections predict outcome in renal transplant recipients. Hypertension. 58: 833-838. https://doi.org/10.1161/HYPERTENSIONAHA.111.176594
Zanoli L, Lentini P, Briet M, Castellino P, House AA, London GM, Malatino L, McCullough PA, Mikhailidis DP, Boutouyrie P (2019) Arterial Stiffness in the Heart Disease of CKD. J. Am. Soc. Nephrol. 30: 918-928. https://doi.org/10.1681/ASN.2019020117

Zoungas S, Kerr PG, Chadban S, Muske C, Ristevski S, Atkins RC, McNeil JJ, McGrath BP (2004) Arterial function after successful renal transplantation. Kidney. Int. 65: 1882-1889. https://doi. org/10.1111/j.1523-1755.2004.00595.x 